\title{
Transcripts of Gender, Intimacy, and Islam in Southeast Asia: The "Outrageous" Texts of Raja Ali Haji and Khatijah Terung
}

\author{
Mohd Faizal Musa (D)
}

check for updates

Citation: Musa, Mohd Faizal. 2021. Transcripts of Gender, Intimacy, and Islam in Southeast Asia: The "Outrageous" Texts of Raja Ali Haji and Khatijah Terung. Religions 12 219. https://doi.org/10.3390/ rel12030219

\section{Academic Editors:}

Maznah Mohamad and Enzo Pace

Received: 7 February 2021

Accepted: 17 March 2021

Published: 21 March 2021

Publisher's Note: MDPI stays neutral with regard to jurisdictional claims in published maps and institutional affiliations.

Copyright: (C) 2021 by the author. Licensee MDPI, Basel, Switzerland. This article is an open access article distributed under the terms and conditions of the Creative Commons Attribution (CC BY) license (https:// creativecommons.org/licenses/by/ $4.0 /$ )
Institute of the Malay World and Civilization, National University of Malaysia, Bangi 43600, Malaysia; mfaizalmusa@ukm.edu.my

\begin{abstract}
It is generally perceived that Malays—who are predominantly Muslims—are comparable with the notion of politeness, aligned with moral axioms, and behave in ways copiously guided by religion. Casual sex and other forms of sexual "deviance" are typically attributed to foreign influences, most popularly, Westernisation. New social trends among this community, such as the emphasis on male dominance, changing prescriptions about the functions and expectations of sex, receptiveness towards the body and emotion, exposure to sex education, and openness to sexual discourse are often attributed to the "immoral" West. Yet, forms of sexual behaviours depicted in the writings of notable Malay religious and literary personages reveal surprising insights into the MalayMuslim milieu of 19th-century Riau. A variety of sexual practices and relations are expressed through these writings. This article adopts a historical-sociological framework to examine the "artisan tools" of textual materials as in the Kitab Pengetahuan Bahasa (Book of Linguistic Knowledge) by Raja Ali Haji and Perhimpunan Gunawan bagi Laki-Laki dan Perempuan (A Compendium of Charms for Men and Women) by Khatijah Terung. The "outrageous" sexual depictions in these texts are discussed and analysed, in part to debunk the idea of a "sexual revolution" or "sexual licentiousness" as emanating from an external culture.
\end{abstract}

Keywords: sexual conduct; sexology; Raja Ali Haji; Khatijah Terung; Malay dictionary

\section{Introduction}

There are types of sexual behaviours deemed dysfunctional or incorrect by certain communities but functional or useful by others. For example, in Melanesia, what is seen as homosexual behaviour in the West is considered a healthy sexual custom or education for teenage boys, and known as "ritualized homosexuality" or "boy inseminating [sic] practices" (Herdt 1993, pp. vii-xliv). Meanwhile, urut batin or the "manhood massage" that is practised by Malay men is viewed as profane and controversial even though it is considered a perennial health practice as well (Mohd Faizal 2015).

This paper aims to examine and understand the sexualities of people in the Malay archipelago. It focuses on two texts written by notable personages in 19th century Riau, which was part of the sultanate system in the Malay world before becoming a province of modern-day Indonesia. ${ }^{1}$ These texts were written in the Malay language by authors who were Muslims, and are significant when read against prevailing assumptions about sexual mores and behaviours of Malays.

It is often assumed that Malays are innately courteous and uphold morality and decency. It is also alleged that they began experiencing social problems involving sexuality only after the encroachment of Western influence. Such preconceptions can be found in various academic and non-academic writings up to today.

For instance, in a seminar presentation titled "Wajah Moral Masyarakat Melayu Pascamoden: Antara Realiti Harapan dan Gagasan Pendidikan Moral Tinggi (The Moral

\footnotetext{
1 After the fall of the Malacca sultanate to the Portuguese in 1511, Riau became regarded as the cultural centre of the Malay world.
} 
Face of Postmodern Malay Society: Between Hopeful Reality and the Idealism of High Morality in Education)", Mohd Azhar et al. (2004) asserted that Western influence was the prime reason for the moral decadence of Malays, as it had lured them into casual sex, homosexuality, and having overt sexual discussions (p. 7). Similarly, in "Kehadiran Barat dan Kesannya Terhadap Kesusasteraan Melayu (The Arrival of the West and the Impact on Malay Literature)", Mohd Zariat (2006) argues that obscenity, unnatural sex, and erotica are Western imports, all of which go against Malay culture and behaviour driven by Islam. This thinking appears in Ungku Maimunah (2019) as well. In "Sendeng-Barat Dalam Sastera Melayu Moden: Cabaran Sebuah Cengkaman (The Tendency Towards the West: The Challenge of Freedom from Oppression)", she blames the West for these "social ills" while reinforcing the idea that originally, Malay-Muslim culture was pure, refined, and sanctified.

Malay sexual behaviour and practices were far more complex than the claims stated above. At minimum, writings that date back to the 19th century suggest that this community did not have to rely on the West for guidance in their sexual explorations.

\section{Materials and Method}

This article employs a historical-sociological framework to counter the misconceptions outlined above. Such an approach allows for present day evidence to be analysed against what a study of the past reveals. In other words, "evidence coming from direct observation of the present and from indirect observation of the past" (Tilly 2001, p. 6753). Analysis through this framework, which recognises that spatial and temporal contexts give rise to particular historical episodes (ibid, p. 6754), can help shed light on what Malay sexuality looked like in the 19th century, and how today's Malays may be able to learn from the past. The framework calls for a review of primary and secondary historical sources, which includes what historian Charles Tilly terms as "artisan tools" (ibid, p. 6755).

There are various published Malay classical texts discussing sex, including Tajul Muluk (Magic Book) translated by Syeikh Hassan bin Syeikh Ishak Fatani, whose translation was completed on 26 May 1833 (Syeikh Hassan n.d.). Another famous one is Kitab Mujorabat (A Compendium of Knowledge) "completed on 20th August 1883" (Yusmilayati Yunos 2011, p. 7). However, neither text is considered original work, being translations and adaptations from Arabic and Persian texts. The main focus is also on medicine with chapters or parts concerning on sexual health. Other significant works are Kitab Hukum Jima' (Book on The Rules of Sex) printed in Mecca 1891 and "being reprinted many times and highly regarded in South East Asia" (van Bruinessen 1993, p. 165); as well as Kitab Bersetubuh Dalam Islam (Books on Lovemaking in Islam) by R. H. Moehammad Joenoes Ahmad (n.d.), which is an adaptation of the previous one. These texts do not just cover topics on sex but also discuss Islamic jurisprudential matters. There are many other sources from the Malay-Indonesian world, many of which are still understudied. For this article, I will focus on two texts written in Malay, by authors who are well-known in Malay literary studies, particularly Raja Ali Haji. The two authors are both from Riau, one of the most notable centres of Malay cultural and literary production until the early 20th century.

For this article, the artisan tools are two 19th century texts, the Kitab Pengetahuan Bahasa (Book of Linguistic Knowledge) by Raja Ali Haji and Perhimpunan Gunawan bagi Laki-Laki dan Perempuan (A Compendium of Charms for Men and Women) by Khatijah Terung ${ }^{2}$.

Studies on sexual conduct have typically focused on a few macro social trends such as the emphasis on male dominance, the change in perception towards prescribed functions and expectations of sex, the receptiveness towards the body and emotions, challenges against power relations, the exposure to sex education, and openness to sexual discourses

2 I would like to thank Nur Fatin Afiqah Halim from the National University of Singapore for her valuable assistance in translation work for this article. 
(see Shilling 1996; Turner 1996; Blum 1997; Ben-Ze'ev 2000; Hite 2000; Tannahill 2001; Milner and Browitt 2002; Laqueur 2003).

This article uses the Kitab Pengetahuan Bahasa and Perhimpunan Gunawan bagi Laki-Laki dan Perempuan to examine the relationship between some of these trends and depictions of sexual behaviour in the Malay world at the time. In such a pre-modern setting, the absence of instruments such as social media makes data collection more challenging. Nevertheless, since traditional Malay literature is participative in nature- that is, readers are involved in the process of creating a piece of literary work (Ding 2003, p. 126) -this offers another route in which past practices can be uncovered. In this study, I utilise the works by Raja Ali Haji and Khatijah Terung as temporal documents; that is, to show the social conditions or more specifically, the depictions of sexual behaviour and practices of Malays here in the 19th century.

\section{Raja Ali Haji and the Kitab Pengetahuan Bahasa}

\subsection{Background}

Raja Ali Haji (1808-1873) was a third-generation descendant of Raja Haji Fi Sabilillah, a renown Bugis warrior and also crown prince of the Johor-Riau sultanate (1777-1784). He was a prolific writer and theologian, and among his many works was the Kitab Pengetahuan Bahasa, a dictionary believed to have been authored in the mid-19th century (Roza Ellya 2012, p. 173). Raja Hisyamudin and Bharuddin (2012) date the completion of this book to 1858 but also note that it was printed only in 1929 by the Al-Ahmadiah Press (p. 332). Hashim (2002), however, writes that the dictionary was arranged in 1857, eight years after Raja Ali produced the Bustan al-Katibin (Manual on Malay Grammar). The Kitab Pengetahuan Bahasa was only published in 1927 by Matba'ah al-Ahmadiah through the initiative of Raja Haji Umar bin Raja Hassan, a grandson of Raja Ali Haji (p. 69).

The Kitab Pengetahuan Bahasa as it is available today is not the complete version. This is because a few sections are missing.

A part of the dictionary was already published in the year 1928, not in Betawi, but in Singapore, with the title Kitab Pengetahuan Bahasa, that is, Kamus Logat Melayu Johor Pahang Riau Lingga. However, other sections of the original book did not survive a fire accident before getting published (Maier 2001, p. 177).

Nevertheless, to this day, this work has an eminent status and can be regarded as part of the Malay canon. It is not only "the first Malay language dictionary in the Malay world" but also, "a Malay encyclopaedia with around 2000 basic clauses" put together as a continuation of the Bustan al-Katibin, which Raja Ali hoped would build Malay as a standard language in his country (Ellya 2012, p. 173).

Employing a kaufah approach, this "monolingual encyclopaedic dictionary" did not list its entries alphabetically but was based on the first and last syllable of each word (Raja Hisyamudin and Bharuddin 2012, p. 332). It is a form of language-application document plus slang of the Malay community during that period. This means that the Kitab Pengetahuan Bahasa recorded public speech and expressions of its time; in other words, its source was members of society then (Ellya 2012, p. 186).

While the Kitab Pengetahuan Bahasa provides valuable inputs of experiences of the 19th century Malay masses, the Perhimpunan Gunawan bagi Laki-Laki dan Perempuan discussed later was more inclined towards documenting palace voices.

Indeed, various historical texts, such as the writings of Khadijah Terong of Pulau Penyengat, Riau, the famous Sejarah Melayu, Tuhfat al-Nafis, Tajul Muluk, Candraning Wanita, and Suluk Tambangaras, some of which date back to the 15th century, and other archaeological artefacts, provide us with more than sufficient empirical evidence that the theme on sexuality and gender in the Malay world was an integral part of the social life of the locals. It was certainly a lived reality. Inevitably, since the texts and artefacts were istana-centric (palace-centric) in nature, the focus of attention was mainly on the sexual life of aristocrats and those living in the istana and hardly ever on those living outside this sphere, such as the peasants, merchants, and seafarers (Shamsul and Fauzi 2006, p. 62). 
Combined, however, the content of both these works can be said to reflect the overall situation in Riau in that era, including views and practices related to sex and sexuality.

Why refer to a dictionary like the Kitab Pengetahuan Bahasa to study the sexual behaviours of Malays? This is because it contains many references to this subject as recorded by Raja Ali Haji along with examples of applications that likely illustrate the conditions of the then Riau society.

\subsection{Sexual Words in the Kitab Pengetahuan Bahasa}

Among the words listed in the Kitab Pengetahuan Bahasa is ancuk, which is most akin to the term "fuck" in English. In his description of ancuk, Raja Ali Haji starts by explaining that he had not planned to include this word as it was "not refined to be spoken of". Nevertheless, despite its "vulgarity", he decided to keep it as a record of "language knowledge" (Raja Ali 2010, pp. 56-57).

Ancuk is defined as "when a man and a woman have the intention to engage in the act of carnality, where their genitals are revealed to the eyes of the public, unless they are both in a completely quiet place". While mengancuk refers to sexual positions prevalent at the time, where "a man engages in the act of ancuk while sitting, lying down or standing", diancuk is when "a woman allows herself to be penetrated by a man by lying down on her back or sideways, or even in a leaning position" (pp. 56-57).

Similar to the word ancuk is ayok, whose inclusion Haji Raja Ali (2010) again attributes to wanting to "add to the language" (pp. 70-71) even though it is another "vulgar" term. He writes,

Ayok is the act of a man inserting his penis into the vagina for pleasure due to syahwah bashariyyah (carnal desire). The woman lies on her back while the man squats with her thighs resting on his. When he is inserting his penis into her, the man will move his butt so that the penis probes into the vagina before he partly pulls it out again. This also pleasures the woman. Sometimes, the woman will move her butt to the left and right to pleasure the man, or to have his penis push against the walls of her vagina ... Sometimes, there are instances of penetration from the side and the back; in others, the man will stand while the woman lies down. This depends on the respective preferences of those involved. This continues until the man climaxes. It is even better to wait for the woman to climax. The discussion on adab al-jima (sexual etiquette) continues in the Arab and Malay books. (pp. 70-71)

As a renowned theologian, Raja Ali Haji's vivid description of the word ayok is astounding. He could have omitted this word completely from the Kitab Pengetahuan Bahasa, or even if its inclusion was necessary, he could have avoided going into such detail. His aim, it would thus seem, was to give his readers a comprehensive sex education, specifically, on copulation techniques.

At least three sexual acts among 19th century Malays are discernible from the word ayok in the Kitab Pengetahuan Bahasa. Berayok is explained as the act of peeping or spying at those engaged in coitus; "'Berayok', is when one whispers to the other, 'Why is that bed moving?' and the other person replies, 'Mr Jantan is having sex with his woman on the bed. Let's just keep quiet and pretend we're asleep" (ibid, p. 72). Terayok is used in relation to a mother's role in setting up a woman to seduce her son for sex; "Terayok, as someone mentions to another: 'My mother has asked Maimunah to massage me every night. While massaging and rubbing me, we became aroused and ended up having sex, once or twice'" (ibid).

Observe the explanation used with regards to the act of "massaging" every night until intercourse takes place. With the explanation for the word berayok-ayokkan, Raja Ali Haji provides a window into potential sexual practices-casual sex and regular changing of partners-in the Malay community at the time.

Berayok-ayokkan, as one tells the other: "Kampung Ilir seems vile and dirty as well as obscene as they engage in sex with one another. He had sex with another man's wife and 
that man had sex with his. As there is regular intercourse happening among themselves in that village, we should avoid marrying the people there as they are really obscene and vulgar" (ibid, p. 73).

Why is it that Raja Ali Haji, as Jan van der Putten (2002) notes, "gives full attention, namely [to] that of sex and bodily functions" (p. 424)? Is this because sex indeed occurred freely and uncontrollably at the time?

The definition of amput in the Kitab Pengetahuan Bahasa, a word considered "more crude than 'ayok'" (Raja Ali 2010, p. 97), would suggest that this was the case. Using an example of male sailors who engage prostitution services; Raja Ali Haji notes,

As told by someone: "Where are the drunk and singing naval sailors going to?" And his friend replies: "Where else but the brothel. The longhouse is where they 'beramput' or engage in sex." This language is considered very crude but since this is done to differentiate the word from other similar words, nothing can be done about it. Unlike other words with a similar meaning, 'amput' should not be verbalised out loud but articulated within one's heart. (ibid, pp. 97-98)

According to van der Putten (2002), this description by Raja Ali Haji was a reflection of brothels around the port in Tanjung Pinang, Riau, in the mid-1860s.

The illustration shows Raja Ali Haji's severe criticism of a phenomenon which must have been a thorn in his flesh. In the mid-1860s the harbour of Tanjung Pinang, just across the bay of Penyengat, was used as a Dutch base for warships sailing to the east coast of Sumatra to carry out punitive expeditions against insurgent rulers. Many sailors came to Tanjung Pinang to visit the brothels and other establishments on their way to and from these expeditions in Sumatra (p. 425).

Importantly, he defended Raja Ali's depiction, insisting that there were many other words in the Kitab Pengetahuan Bahasa not related to sex, and that any sexually-related term was painted in a negative light ("bad traits and misconduct in order to show the readers how they should not behave" (van der Putten 2002, p. 426). Moreover, he believed that even though the definition of a term may have been obscene, it still needed to be said as "Malays should know these words and when to use them" (ibid, p. 427).

Raja Ali Haji's preoccupation with sexual depictions is only part of his purpose, if we analyse and weigh the poems he added into the Kitab Pengetahuan Bahasa (Raja Ali 2010, pp. 301-6). Specifically, there was a 42-verse poem under the word tarak, which was defined as, "one who restricts their food intake, is socially detached as well as practises a routine verbally or through their actions. In other words, abstaining from immorality. It can also refer to something beyond worldly pursuits" (p. 301).

In his elaboration, Raja Ali criticises members of the tariqa (order) and condemns the ulama (theologians) whose knowledge is "nominal". He writes about one theologian who "deceived people", and even took advantage of female students, "engaging in sexual activities with them in his house for a month before releasing them" (pp. 301-6). He uses the 42 -verse poem to elaborate on the behaviour of the immoral theologian, at the same time seized the opportunity to engage in sex pedagogy.

In this poem, Syair Luk Luk, the theologian is one Syeikh Pokok Buta-buta, "known" for having ilmu isi or knowledge from "those who have been led astray from God, who are unafraid of heresy and false beliefs" (pp. 301-2). This Syeikh Pokok Buta-buta was approached by someone "disguised as an ideal woman [ ... ] with very long hair" (ibid). The poem names this "fake woman" as Siti Luk Luk, daughter of Tun Syeikh Malim Golok.

Siti Luk Luk, or the "make-believe woman" stayed with the daughters and wife of Syeikh Pokok Buta-buta until one day, the theologian became aroused and desired after her. "Luk Luk replied softly, 'Alright sir, I will comply". He "hungrily viewed her akin to a fish ... ready to be eaten" (p. 303).

The plot of the poem then takes a turn when Luk Luk tells Syeikh Pokok Buta-buta's virgin daughters that with a certain ritual, one's wishes can come true. Luk Luk went on, "My wish is reasonable ... I ask to be a male ... that is the act" (p. 304). Since Luk Luk was already a man, he then showed his penis to the unsuspecting women and they fell for 
his deceits. The following verses of Raja Ali Haji's Syair Luk Luk illustrates this scenario and the intensity of the sexual acts that ensued.

"I have been changed,

From the groin, emerged a penis,"

The young maidens, upon hearing

Came to crowd, all three of them.

Standing nigh they stripped off his garment,

Caressing Luk Luk's penis,

They exclaimed: "By the power of the Almighty,

It took brief seconds to change."

They asked: "What is the use of this,"

Luk Luk replied: "I'm not sure, my lass,"

The youngest maiden then said,

"We saw this on Father."

"Under the glimmer of the full moon,

He was making love to Mother,

Prolonged penetration into her hole,

Arousing Mother with intense titillation."

"Mother was overtly pleasured,

Moaning longingly for his penis,"

She beckoned, "Luk Luk come over,

Do me for a while?"

Luk Luk got up mid-coitus,

While asking how it felt,

She replied: "Don't leave just yet,

It's enticing like korma [dates]."

Then the oldest desires too

She said: "Stop, sister,

Let me experience the hairy tool,

Should it be pleasant, I can come back for more again."

Luk Luk turned to the oldest,

He did her once or twice,

The youngest bantered,

"I don't want to be disappointed too."

Luk Luk turned to the youngest

With whom he dealt with, deflowering her,

Beyond the mosquito net, within the bed curtain

Fluid gushing everywhere.

After finishing the three of them,

The news spread to their friends,

Everyone wants a taste of him,

Obtaining his penis while under abstinence.

Luk Luk dealt with all the women,

Striking one after another, 
Some unashamedly complimented,

They said, "your penis feels good."

Your penis is in slow motion,

Rock my buttocks to make sure it is in action,

As soft as Lophatherum ${ }^{3}$

"What can be done in this abstinence."

"I do not want, and I do not like,

The penis of the evil teacher,

But the penis from paradise,

As it quenches my thirst."

Thus such is the case, day by day,

After isyak [night prayers] till the wee morning

One by one was copulated,

When the Lebai [cleric] desires, many ran.

The Lebai's wife heard the bizarre news,

Luk Luk was called into the room,

As soon as he came, his penis was examined,

He stripped his clothes, and asked to be stroked.

The Lebai's wife had coitus with the lad,

Her belly and breast heaving up and down,

It was different with Lebai,

Who was like a goat while this lad was like a horse.

Thus such is the case night and day,

Satisfying the desires of the maiden,

Playing with the racy penis,

Shaking and moving vigorously.

The poem above presents a remarkable elaboration of the word tarak that initially intends to demonstrate the hypocritical character of some theologians. As mentioned, it is also most likely that Raja Ali Haji was offering some sex education. The necessity of including this poem to help define the meaning of tarak is questionable especially since it is very explicit in describing the sexual acts. Regardless, it enabled Raja Ali Haji to present step-by-step, the techniques of having sex (even in the case of intercourse that is forbidden). Several observations are worth highlighting.

a. The first step involved having the woman fondle and play with the male genitalia (Standing nigh they stripped off his garment/Caressing Luk Luk's penis).

b. It is apparent that the sexual activity of their parents triggered immense curiosity of Syeikh Pokok Buta-buta's virgin daughters ("We saw this on Father" / Under the glimmer of the full moon/He was making love to Mother/Prolonged penetration into her hole/Arousing Mother with intense titillation").

c. Raja Ali Haji also explains that it is important that the penis is not flaccid to ensure sexual pleasure during sex (While asking how it felt/She replied: "Don't leave just yet/It's enticing like korma [dates]").

d. Apart from overt sexual activity, a verse in this poem also depicts the practice of communal sex by Malays in that period (She said: "Stop, sister/Let me experience the hairy tool/Should it be pleasant, I can come back for more again"/ Luk Luk

"Sayur kelorak", a type of plant eaten in traditional Malay "salads". 
turned to the oldest/He did her once or twice/The youngest bantered/“I don't want to be disappointed too").

e. The orgy was a mass deflowering ceremony (Luk Luk turned to the youngest/With whom he dealt with, deflowering her), and illustrated as being so astounding that, "Beyond the mosquito net, within the bed curtain/Fluid gushing everywhere"). It did not stop there as when the three sisters invited their friends to join in, some claimed that they would rather be with Luk Luk than Syeikh Pokok Buta-buta whose penis was deemed no comparison (Everyone wants a taste of him/Obtaining his penis while under abstinence).

The description of the sexual exploits between Syeikh Pokok Buta-buta's wife (Mak Lebai) and Luk Luk would render her a "cougar" 4 in today's world, but more importantly, the depiction portrays Malays of that period as having pleasurable sex. In fact, Luk Luk who was much younger, engaged in intercourse with Mak Lebai "night and day", until they trespassed into forbidden intercourse (Playing with the racy penis/Shaking and moving vigorously). It is unclear if Luk Luk was a gerontophile (Janssen 2015) with erotic inclinations towards someone older, but it is interesting that Raja Ali Haji felt this aspect worthy of inclusion in his poem.

The women in this poem are very articulate in conveying their sexual desires in the most explicit way possible (Some unashamedly complimented/They said, "your penis feels good"). In Malay society of the 19th century, it would appear then that women were not sexually passive but rather, free to choose and express themselves. This point is discussed further below.

There are other works by Raja Ali Haji featuring the sexual practices of Malays, including the Syair Suluh Pegawai (Poem on To Know the Official-on marriage rules), which dates back to 1866 (Raja Ali 1993, p. 117). While it is important to discuss this work, I have not done so because unlike the poem in Kitab Pengetahuan Bahasa, Syair Suluh Pegawai is not as clear and direct given it is filled with figurative language.

Suffice to say, if we compare Syair Suluh Pegawai and Syair Luk Luk, it is apparent that Raja Ali Haji is capable of more refined writing, one that would not be considered "obscene". I would therefore argue that in the Kitab Pengetahuan Bahasa, Raja Ali Haji's approach was deliberate, to illustrate sexual acts; depictions that he possibly did not regard as pornographic. It is important to state that I am not interested in debating whether the poems were intended as pornography or erotica. This is because I believe that such definitions are relative, hence the importance of taking into account the period in which they were produced. ${ }^{5}$

Instead, I am curious about the reason behind Raja Ali Haji's decision. Was it because he experienced erectile dysfunction or impotence? In 1855, Raja Ali Haji's letter to Von de Wall, the Dutch Resident's assistant residing in Tanjung Pinang, Riau, ${ }^{6}$ conveyed that he was "anxious about his lack of sexual potency" (Maier 2001, p. 165) ("God, God, is there no longer a cure for this impotency over there?"). It is also worth mentioning that impotent or

4 See (Kershaw 2009) for an explanation of this term. Sarah Knapton (2014) argues that one of the reasons for the cougar phenomenon is the incompetence of some men to satisfy their female partner after reaching the age of 40. In Raja Ali Haji's poem, Mak Lebai (Syeikh Pokok Buta-buta's wife) is shown as preferring Luk Luk over her husband who lacks the stamina of the younger man during intercourse (It was different with Lebai/Who was like a goat while this lad was like a horse).

5 As Pope et al. (2007) write,

One difficulty that occurs when trying to define pornography is that any acknowledgement of moral or artistic sensibilities is necessarily bound by social values. To distinguish pornography from some other product or expression requires the definition to be placed within the changing contexts of society as a whole. Because of this, we should consider that a cultural or sub-cultural deeming of what is pornographic does more to identify cultural or sub-cultural values and norms than it does pornography or erotica. This leads us to observe that it may well be that what constitutes pornography and erotica varies not only between groups, but also between individuals within a group. It is also likely to vary with the passing of time-what was considered pornographic perhaps in the early 1900s may now be considered erotic, or even slightly foolish. (p. 2) 
otherwise, Raja Ali Haji had four wives and many children (ibid., p. 172), as well as young concubines (Matheson Hooker 1995, p. 36).

In addition to the detailed elaborations of certain words, Syair Luk Luk talks about cross-dressing, specifically, a male character disguising himself as a woman with the intention of deceiving the virgin daughters of Syeikh Pokok Buta-buta. As noted already, the female characters also had sex with Luk Luk even though they knew (or believed) that Luk Luk was a woman who had changed her gender through a special chant. This could be interpreted as Raja Ali Haji's acknowledgment—consciously or subconsciously—of same-sex desire.

Is the poem's depiction of women's drive for sex the norm among 19th century Malays? It would appear that Raja Ali Haji had a general predisposition towards documenting sexual practices as the Kitab Pengetahuan Bahasa also showed Malay men as indulging in adultery, voyeurism, casual sex, sodomy, bestiality, and masturbation (Raja Ali 2010, p. 101). Moreover, he not only chose sex addiction to explain the word "addiction" (ibid, p. 379) but also described several adjectives showing what Malays perceived as ideal female genitalia. For example, female genitalia was his preferred descriptor for the word cekih, that is to see the inside of something; tercekih, is "akin to a woman squatting, revealing her vagina, or innards of shells" (Raja Ali 2010, p. 468).

Likewise, to explain tembam or "fleshy", he wrote:

Fleshy: something that is highly regarded, indeed a distinctive word in this language that refers to the vagina. A fleshy vagina is one that is wide and meaty at the top, so it looks high. The bone can also be felt when the hand is deep inside and at the side walls of the fleshy hole; and with that giving rise to a wide vagina, tall on the upper side and if seen from the front, it looks like a crab latching onto a surface. Indeed, a fleshy vagina is the most perfect form for many Malays. A vagina is stunning, it can even arouse men with low sexual potency. (ibid, p. 359)

Raja Ali also discussed the quality of a fleshy vagina in verse 105 of Syair Suluh Pegawai; ("the condition for a huge and fleshy vagina" (Raja Ali 1993, p. 323)). Although some readers may find this crude, Raja Ali Haji quickly serves a reminder that this is done to avoid future confusion, and that this too is part of the Malay language. ${ }^{7}$

Worth noting are the different ways in which Raja Ali Haji depicts male and female genitalia. While the latter is described in detail, even though he considered it vulgar, all he says about butuh, the penis, is: "This is a vulgar language, which means the penis of a grown man, none is used for children's penis among the Malays in Johor. Even if there is a word for this among Malays on the east coast, I hear that the language is also refined" (Raja Ali 2010, p. 269). One possible reason for this contrast in treatment may be how the penis symbolises faith to Raja Ali Haji, as seen in his other work, the Tuhfat al-Nafis.

Returning to the earlier question, was the illustration of women's sex drive and addiction in Syair Luk Luk the norm among Malays then or merely a conscious illustration of Raja Ali Haji's imagination? The following passage about women's morality may reveal a little more of his thinking on this matter.

"To know if the woman is immoral is to see if they put on excessive makeup like plucking their eyebrows, putting on mascara and excessive hair oil, cutting finger nails and chewing betel nut, applying candlewax oil on the lips to redden them. And when they walk, they move in a suggestive manner. And if they like a man, they will stare at him intensely. And they like to sit by the doors and windows where they will pretend to look busy when men pass by, when in fact, they are stealing glances at the men; and if the men approach them to talk, these women will pretend to accidentally remove their tops, revealing their breasts; and sometimes when these women are sitting down and there is a man behind, they will pretend to accidentally remove their bottoms, revealing their butt before pretending to be surprised and quickly covering-up. However, upon seeing her in

"Oh sirs who are listening to this speech, do not misunderstand and misinterpret because if I do not explain it like this, those who read this may not have the knowledge and will constantly be questioning the obscurity" (Raja Ali 2010, p. 359). 
that state, the man would have already been aroused and it becomes easy for the woman to have him. Indeed, these are the doings of such women, if they desire the men, it is easy for them. Sometimes, the men pay them to indulge in extra sexual activity and sometimes the women pay the men. Indeed, it is not a covert affair when the women desire for the men, one after another. These are certainly traits of immoral women" (Raja Ali 2010, p. 393).

Likewise, to explain the word birah, that is, metaphorically like an itch that needs to be scratched, or in a state of being lecherous or perverted, Raja Ali Haji again used women and their genitalia as an example, "and sometimes it is declared that a person who indulges in fornication is immoral, as was said by someone: 'So and so is really perverted, always indulging in fornication,' that is, her vagina is always itching" (ibid., p. 263). With the word biang, he wrote, "that is, women like to indulge in frequent sexual activity as her vagina can become achingly itchy if not done often". In other cases, he used animals to explain what he meant about women's sex drive, "as told by someone: 'the cat is really lustful, always wanting to mate'" (ibid, p. 255).

The passages above speak of a bias against women. Raja Ali Haji not only painted them negatively, particularly in comparison to his descriptions about men, but also compared women to animals. His message was clear: women should not be expressive or show their sexual courage and libido. Those who take charge of their sexuality and demonstrate "lust" are considered immoral.

This notwithstanding, there are parallels between Raja Ali's entries of peculiar and unusual sexual episodes in the Kitab Pengetahuan Bahasa-including the introduction to ways of having intercourse and the detailed descriptions of genitalia-and the sexual revolution in the West where "sexuality became politicised and society eroticised" (Hekma and Giami 2014, p. 1). The main difference, however, was that the former were illustrations from a century earlier.

Whatever the motivations of Raja Ali Haji, the Kitab Pengetahuan Bahasa is a valuable resource that sheds light on possible sexual practices and behaviours of Malays at the time. The moral lessons by Raja Ali Haji hide many secrets of the Malays as noted by Al Azhar (1995); "from the lectures in the Kitab Pengetahuan Bahasa, we are made aware of the practical aspects revolving around the way of life, conduct and ideal social customs of the Malays, which always relate back to the understanding of Islam and Malay culture" (p. 45).

\section{Khatijah Terung and Perhimpunan Gunawan bagi Laki-Laki dan Perempuan}

There is a paucity of information about the life of Khatijah Terung, author of Perhimpunan Gunawan bagi Laki-Laki dan Perempuan. The little that exists-attesting to the "invisibility" of women in historical records-indicates that between 1908-1911, she was the fourth wife of Raja Haji Abdullah bin Raja Hassan, a grandson of Raja Ali Haji. When Khatijah married a much older Raja Haji Abdullah, she was estimated to be around 23 to 26 years of age (Watson Andaya 2003, p. 98; Ding 2006, p. 77).

According to Choo Ming Ding (2006), a researcher in Malay manuscripts, Raja Haji Abdullah was a doctor and a syariah kadhi (ibid). He was also said to have mastered many Western languages and had an interest in "writing, drawing, carving and making dolls" (p. 78). In addition, he had a scrapbook containing "nude images of European women torn from printed material from Europe, as well as sketches of the female genitalia" and "nude women models with revealing breasts which became the prime subject matter in the visual art scene in Europe since the Renaissance period, can be found in his work Cempaka Putih and Pahlawan Ferhad" (ibid).

Before marrying Raja Abdullah, Khatijah Terung was a shaman and a member of Rushdiyah Club, a cultural bangsawan (royals) club in Riau. It is believed that her relatives and possibly her own husband backed Khatijah to write the Perhimpunan Gunawan bagi Laki-Laki dan Perempuan to share tips, secrets and magical "things" relating to sex:

Other texts suggest that traditional "female" matters, such as pleasing a husband, continued to concern the wives of Rushdiyah Club members. For instance, a Penyengat woman of commoner origins, Khatijah Terung (1885-1955) became the fourth wife of Raja 
Haji Abdullah ... Known for her mastery of "white magic", Khatijah Terung was quite possibly encouraged to record her knowledge by her husband, himself a prolific writer with an interest in the occult, and by the Bugis-descended women who were now her relatives. The resulting manuscript, Perhimpunan Gunawan bagi Laki-Laki dan Perempuan (A Compendium of Charms for Men and Women), dated 1329 AH (1911), comprised a list of charms by which women could protect their absent husbands, and other "special secrets" that would heighten sexual pleasure and ensure marital fidelity (Watson Andaya 2003, pp. 98-99).

Ding (2006), who studied the 52-page-long Perhimpunan Gunawan bagi Laki-Laki dan Perempuan, explains that this treatise contains 53 techniques to "strengthen the body of one's husband, make a husband attracted to his wife, promote good sex, keep a husband faithful, and ensure a woman remains beautiful". Khatijah's knowledge came from various sources, including a teacher known as Wan Mah (ibid, pp. 78-79).

According to Ding, Khatijah's courage to write about "more than 20 ways to achieve pleasure and the ideal intimacy during intercourse", sent "an implicit message" about how "sexual intercourse [was] not a physical act dominated only by men but that women too could initiate this". He asserts that this was a manifestation of "women who fight for women's emancipation and do not bow down to social pressures, and are thus depicted as dynamic, active, progressive, individualistic and expressive" (ibid, p. 85).

How "dynamic" and "expressive" was Khatijah Terung, and how can what she wrote be considered as one of the more daring depictions of Malay sexual behaviour? The answer may lie in the incantation she mentions (obtained from Wan Mah) - and which possibly strikes some as shocking-about multiplying pleasure from sex:

"This is used to give pleasure to our husband before or during intercourse. So read this incantation. Thereafter, blow towards our genitals. And during intercourse, blow towards both parties' genitals. While reciting this incantation, engage in intercourse with our husband. Certainly, a pleasant and magical and nice and peculiar feeling will come from our genitals. This is the incantation:

A sprig of leaf, a pod of flowers

Adorned with gold ring and diamond

I cloth in the word 'cunt'

My cunt is fleshy, it excites men.

With the slip of the gold ring onto my finger

Embellished with diamond and sapphire

Hitting and clashing both surfaces

Penis thrusting deeply into the cunt.

Adorned with gold ring and diamond

The union will feel heavenly and divine

Pleasant and tranquil, not at all made-up

Forget the world and its contents.

With the grace of the prayer La ilaha illallah Muhammad al-Rasulullah S.A.W.

This incantation will indeed succeed, God willing. And this is partly from Wan Mah from Penang, well-known among men and even the unseen across Penang and Singapore. Walla hu a'lam bissawab". (Khatijah 1911, cited in Ding 2003, p. 43)

Like Raja Ali Haji, Khatijah Terung also mentioned "fleshy cunt" as a criterion of an ideal vagina. Her other incantations are very explicit, with wafak (charms) and diagrams that provide guidance to the procedures of intercourse:

The buttock moves without exhaustion

Several cloves in the cup

Kiss the armpit, fondle the breasts 
The cunt agape, the man enters.

The clitoris branches left and right

It stands big and erect

And so the cunt becomes aroused

Getting thrusted by her partner's penis.

Groping and moving unabashedly,

The penis thrusts into the vagina

That is all hirsute. (ibid, p. 44)

A more explicit and blunt incantation can be seen below.

This is a charm for the cunt so that the vagina would not be so wet but instead, hot and rough like a cat's warm tongue, like the heat in a hot kitchen, like burning coconut shells. As such, for a start, take a bit of limestone and read this incantation:

The broken regenerate, the lost replaced

The ladle fell, the legged scarab

To devour, one desirously waits

For the thrust of the penis into the vagina.

The ferns at the edge of the village

The topple of the angsana [narra] branch

It is not me who has power

But the God of the universe

Probing the right, stabbing the left

Pleasuring and gratifying without dissent

Oh the sharp erect penis

Fluids spurted copiously.

And so blow this incantation into the limestone in our palm and rub it slowly on our vagina and under the armpit. But do not put the limestone on our armpit or privates; but instead carefully spread it across the palm as limestone is scarce. And so rub the palm of our hand on the vulva and the edge of the clitoris. And invite our husband to have sex, by drawing our garment as we spread our thighs to make visible to him our vagina and clitoris. Thus, our husband cannot restrain himself from arousal, sometimes kissing the areas that we have rubbed prior and he will feel pleasured when making love. While he is preoccupied and drunken in ecstasy, we have to read the incantations in his ears. Certainly, he will embrace us lovingly with heightened arousal. With that, his penis will enter the vagina with indescribable pleasure and we will experience immense satisfaction as the penis and thorny girth rub against the vagina and clitoris. And do not hesitate to continue arousing our husband with words and other form of action." Walla a'lam (ibid, p. 52).

Khatijah also suggested that the wife kiss her husband's genitals to improve or maintain his sexual health.

"This beginning is very useful if we want to encourage potency or arouse our husband. [... ] surrounding the [penis] head and prolong the desire with intercourse. And so we need to always kiss him such that our nose sweeps across his whole body. Certainly, there won't be any kind of hesitation for as long as he lives. Also, if we always rub our nose against his sexual organ, surely, his penis will enlarge as well as extend in length and the girth will swell with throbbing veins. And the girth gets redder and shiny due to its stiffness and swelling, and the length increases because a woman's natural oils is very useful for men, likewise for women with men's natural oils. Then, this is partially a hidden secret, therefore, not many are aware unless the women who oppose this art of knowledge and medicine that they [... ] when it comes to the regulations as a wife and other etiquette 
between the couple. Therefore, keeping them both safe in this world and hereafter." Wallaha 'alam (ibid, p. 54).

Khatijah Terung's prescriptions above seem astonishing, especially with the inclusion of oral sex. Among Malays, it is comparable to wild behaviour, infidelity, and difficulty in giving birth (Laderman 1983, p. 151). Moreover, she writes that kissing —and maybe sucking a man's penis-is healthy (Ding 2006, p. 54). Such knowledge is essential, but so is maintaining "etiquette" between a couple, not only to maintain stability in a marriage but also to avoid a wife from looking for other men. During the sexual revolution in the West, the same behaviour, especially a blowjob, would have been perceived as a sign of "masculine sexual privilege" (Mankowski 2010, p. 143).

Perhimpunan Gunawan bagi Laki-Laki dan Perempuan compiled by Khatijah Terung clearly states that the incantations had the ability to subdue one's husband into becoming akin to "our serf". This gender role reversal is one that challenges prevailing male dominance.

This is the start of a supplement to make our husband into our obedient serf as they should, that brings a sense of security, that is, by reading every afternoon with a clear heart and intention without deceit. Certainly, God bestows his blessing and answers to our prayer so that our husband serves us dutifully and is a good advisor" (Khatijah 1911, p. 47).

In my view, many of Raja Ali Haji's illustrations of women and their bodies are very negative, misogynistic, and biased. The writings of Khatijah Terung, on the other hand, challenged the dominant discourse by showing the strength of women as reflected in their influence over men, making the latter their serfs through the power of seduction and sex. In this context, female sexuality is used as a tool to challenge male dominance.

\section{Conclusions}

Malay sexual practices and behaviours are not as "straightforward" as imagined. Is the cause of this enigmatic depiction of sexual practices in both texts studied in this article related to the conditions of a contested religiosity at that time? Or was there more room in personal expressions textually, given that texts as a form of material culture was only consumed by the elite and literate class? These are potential areas of inquiry to be developed through a deeper historical study.

I believe both writers were able to write about sex the way they did as they were belonged to the nobility class. Raja Ali Haji was himself a theologian, and within the inner circle of the ruling elite of the time. Khatijah Terung was married to one of his grandsons. Being part of the royal court, and having the legitimacy of authority in religion, they were certainly shielded from possible derision and beyond being censored. The moral and even sacred aspects of sex punctuated within the writings legitimised their literature. This is unlike today where religious establishment will have the upper hand in monitoring works produced by Islamic artists and writers.

The reason for Khatijah Terung's "depression" mentioned at the end of the manuscript in Perhimpunan Gunawan bagi Laki-Laki dan Perempuan is in need of more studies that could relate to the position of women in nineteenth century Riau. The explanations behind Raja Ali Haji's misogynistic representations of women strikes at a paradox in which women of Riau society at that time were also active producers of literary materials in the form of Syair (Hijjas 2011). Was this—his insecurity—the reason why Raja Ali Haji produced sexually-driven and prejudicial sentences and clauses against women, as gleaned through Kitab Pengetahuan Bahasa? Nevertheless, Khatijah penned Perhimpunan Gunawan between 1908-1911, while Raja Ali Haji wrote Kitab Pengetahuan Bahasa around 1858. There was at least a 40-year interval between the production of the two writings. Perhaps Khatijah was responding to Raja Ali Haji's work, or continuing in his genre of providing didactic guidelines to sexual performance, though with a more female-sensitive variation.

There are no easy answers to these questions. However, this article has shown a lesserknown dimension of possible Malay sexual behaviours and practices of the 19th century, 
one which is not the same as that often simplistically upheld. In fact, we could argue that the depictions in the texts studied here suggest that at one point, Malays possessed remarkable sexual experiences that were manifold, gender-contestable, and even outrageous by today's standards, long preceding the liberal and sexual revolution of the West.

Funding: This research was funded by National University of Singapore, HDRSS Grant 2020/2021.

Conflicts of Interest: The author declares no conflict of interest.

\section{References}

Al Azhar. 1995. Raja Ali Haji: Sebuah Ziarah. Jurnal Filologi Melayu 4: 41-47.

Ben-Ze'ev, Aaron. 2000. The Subtlety of Emotions. Cambridge: MIT Press.

Blum, Deborah. 1997. Sex on the Brain: The Biological Differences between Men and Women. New York: Penguin Books.

Ding, Choo Ming. 2003. Kajian Manuskrip Melayu: Masalah, Kritikan, dan Cadangan. Kuala Lumpur: Utusan Publication \& Distributor Sdn Bhd.

Ding, Choo Ming. 2006. Wajah Terbuka dan Hidup Tertutup: Gender dan Seksualiti dalam Karya Sastera Melayu Riau Pinggir Abad ke 19. Sari: Jurnal Alam dan Tamadun Melayu 24: 73-90.

Ellya, Roza. 2012. Tinjauan Sejarah Terhadap Naskah dan Teks Kitab Pengetahuan Bahasa, Kamus Logat Melayu Johor Pahang Riau Lingga Karya Raja Ali Haji. Jurnal Sosial Budaya 9: 172-94.

Hashim, Musa. 2002. Raja Ali Haji of Riau as the Pioneer in the Establishing Islamic Scholarly Tradition of Language Studies in the Malay World Based on his Bustan al-Katibin and Kitab Pengetahuan Bahasa. Jurnal Filologi Melayu 10: 66-75.

Hekma, Gert, and Alain Giami. 2014. Sexual Revolutions: An Introduction. London: Palgrave Macmillan.

Herdt, Gilbert H. 1993. Ritualized Homosexuality in Melanesia. Los Angeles: University of California Press.

Hijjas, Mulaika. 2011. Victorious Wives: The Disguised Heroine in 19th-Century Syair. Singapore: National University of Singapore Press.

Hite, Shere. 2000. The New Hite Report: The Revolutionary Report on Female Sexuality (Updated). London: Hamlyn.

Janssen, Diederik F. 2015. 'Chronophilia': Entries of Erotic Age Preference into Descriptive Psychopathology. Medical History 59: 575-98. [CrossRef] [PubMed]

Kershaw, Sarah. 2009. Rethinking the Older Woman-Younger Man Relationship. New York Times, October 14. Available online: http:/ / www.nytimes.com/2009/10/15/fashion/15women.html?pagewanted=all\&_r=0 (accessed on 14 February 2013).

Khatijah, Terung. 1911. Perhimpunan Gunawan bagi Laki-Laki dan Perempuan. In Ding Choo Ming 2002. Lampiran: Khatijah Terung dengan Karyanya Perhimpunan Gunawan bagi Laki-Laki dan Perempuan (Bahagian 1). Jurnal Filologi Melayu 10: 34-54.

Knapton, Sarah. 2014. The Cougar Phenomenon: Why Older Women Should Choose Young Lovers. The Telegraph, October 23. Available online: http://www.telegraph.co.uk/news/science/11181138/The-Cougar-phenomenon-why-older-women-shouldchoose-young-lovers.html (accessed on 7 August 2016).

Laderman, Carol. 1983. Wives and Midwives: Childbirth and Nutrition in Rural Malaysia. London: University of California Press.

Laqueur, Thomas W. 2003. Solitary Sex: A Cultural History of Masturbation. New York: Zone Books.

Maier, Hendrik M. J. 2001. Raja Ali Haji dan Hang Tuah: Arloji dan Mufassar. Sari: Jurnal Alam dan Tamadun Melayu 19: 159-78.

Mankowski, Diana L. 2010. Gendering the Disco Inferno: Sexual Revolution, Liberation, and Popular Culture in 1970s America. Ph.D. thesis, University of Michigan, Ann Arbor, MI, USA.

Matheson Hooker, Virginia. 1995. Revisiting Riau with Knowledge: Teaching Texts and Concepts. Jurnal Filologi Melayu 4: 3-40.

Milner, Andrew, and Jeff Browitt. 2002. Contemporary Cultural Theory. Crows Nest: Allen \& Unwin.

Moehammad Joenoes Ahmad, R.H. n.d. Kitab Bersetoeboeh Dalam Islam. Tanjung Pinang: Islamic School Pejnengat.

Mohd Azhar, Abd Hamid, Mohd Koharuddin Balwi, Muhamed Fauzi Othman, and Othman A. Kassim. 2004. Wajah Moral Masyarakat Melayu Pascamoden: Antara Realiti, Harapan dan Gagasan Pendidikan Moral Tinggi. Paper presented at Seminar Antarabangsa Nilai dalam Komuniti Pasca Modenisme (SIVIC 2004). Hotel City Bayview Langkawi, Langkawi, Malaysia, September 4-6. Available online: http:/ / repo.uum.edu.my/2158/ (accessed on 15 September 2014).

Mohd Faizal, Musa. 2015. Sakit Tuan: Beberapa Nota Kearifan Melayu. In Bhakti Pendeta: Mengenang Jasa dan Sumbangan Profesor Dato' Dr. Othman Md Yatim Dalam Budaya, Warisan dan Sejarah Malaysia. Edited by Abdullah Zakaria Ghazali and Mohd Supian Sabtu. Kuala Lumpur: Persatuan Muzium Malaysia, pp. 266-307.

Mohd Zariat, Abdul Rani. 2006. Kehadiran Barat dan Kesannya Terhadap Kesusasteraan Melayu. Jurnal Pengajian Melayu 17: $330-61$.

Pope, Nigel, Kevin Voges, Keri-Ann Kuhn, and Ellen Bloxsome. 2007. Pornography and Erotica: Definitions and Prevalence. In Proceedings of the 2007 International Nonprofit and Social Marketing Conference Social entrepreneurship, Social Change and Sustainability. Edited by Gillian Sullivan Mort and Margee Hume. Brisbane: Griffith University. Available online: http:/ / eprints.qut.edu.au/27 717 / (accessed on 4 June 2014).

Raja Ali, Haji. 1993. Puisi-Puisi Raja Ali Haji. Edited by Abu Hassan Sham. Kuala Lumpur: Dewan Bahasa dan Pustaka.

Raja Ali, Haji. 2010. Kitab Pengetahuan Bahasa. Kuala Lumpur: Yayasan Karyawan.

Raja Hisyamudin, bin Raja Sulong, and Che Pa Bharuddin. 2012. Penggunaan Ayat-Ayat Al-Qur'an oleh Raja Ali Haji di dalam Karya Beliau Thamarat al-Muhimmah. Paper presented at the Second Annual International Qur'anic Conference. Centre for Quranic Research, University Malaya. Available online: http:/ / eprints.um.edu.my/14053/ (accessed on 27 November 2016). 
Shamsul, Amri Baharuddin, and bin Sukimi Mohamad Fauzi. 2006. Making Sense of Malay Sexuality: An Exploration. Sari: Jurnal Alam dan Tamadun Melayu 24: 59-72.

Shilling, Chris. 1996. The Body and Social Theory. London: Sage Publications.

Syeikh Hassan, bin Syeikh Ishak Fatani. n.d. Tajul Muluk. Patani: Maktabah Bin Halabi.

Tannahill, Reay. 2001. Sex in History. London: Abacus Books.

Tilly, Charles. 2001. Historical Sociology. In International Encyclopedia of the Social and Behavioral Sciences 10. Amsterdam: Elsevier, pp. 6753-57.

Turner, Bryan S. 1996. The Body and Society. London: Sage Publications.

Ungku Maimunah, Mohd Tahir. 2019. Sendeng-Barat Dalam Sastera Melayu Moden: Cabaran Sebuah Cengkaman. MANU $30:$ 1-45. van Bruinessen, Martin. 1993. Kitab Kuning dan Perempuan, Perempuan dan Kitab Kuning. In Wanita Islam Indonesia Dalam Kajian Tekstual dan Kontekstual. Edited by Lies M. Marcoes-Natsir and Johan Hendrik Meuleman. Jakarta: INIS, pp. 165-74.

van der Putten, Jan. 2002. On Sex, Drugs and Good Manners: Raja Ali Haji as Lexicographer. Journal of Southeast Asian Studies 33: 415-30. [CrossRef]

Watson Andaya, Barbara. 2003. Gender, Islam and the Bugis Diaspora in Nineteenth and Twentieth-Century Riau. Sari: Jurnal Alam dan Tamadun Melayu 21: 77-108.

Yusmilayati Yunos. 2011. Mujarabat Jawa Melayu: Satu Perbandingan Teks. Ph.D. thesis, Institute of Malay World and Civilization, National University of Malaysia, Bangi, Malaysia. 